\title{
Population Studies
}

\author{
Editor: E. Grebenik
}

Vol.41, No. 1, March 1987 Contents

J. Cleland and C. Wilson Demand Theories of the Fertility Transition: an Iconoclastic View

J. Hecht Johann Peter Sussmilch: a German Prophet in Foreign Countries

J. LANDERS Mortality and Metropolis: the Case of London 1675-1825

G. Feeney and J. Yu Period Parity Progression Measures of Fertility in China

M. N. Bhrolchain Period Parity Progression Ratios and Birth Intervals in England and Wales, 1941-1971: a Synthetic Life Table Analysis

N. Goldman, C. F. Westoff and L. E. Paul Variations in Natural Fertility: the Effect of Lactation and Other Determinants

G. SANTON Reassessing the Contraceptive Effect of Breastfeeding

S. Mitra About the Effect of Changes in Age-specific Mortality on Life Expectancy

J. W. VAupel A Rejoinder to Mitra

Book Reviews

Subscription price per volume of 3 parts $£ 24.00$ (US\$60.00) post free. Single parts of current volume $£ 9.00$ (US\$24.00) post free. Details of back issues on request.

Published by the Population Investigation Committee, London School of Economics, Houghton Street, Aldwych, London WC2A 2AE.

\section{Off-beat Biologist}

\section{The autobiography of Alan S. Parkes}

Sir Alan Parkes divides his story inı six parts. Part I comprises a bird's eye survey of his career from early days to retirement and after, the emphasis being on his thirty years' service with the Medical Research Council. Part II describes the greater part of his original work in, among others, chapters entitled Studies in Mammalian Reproduction, Exciting Times in Endocrinology, and The Rise of Cryobiology. Part III records his contact with organisations dealing mainly with man, and Part IV with those dealing with animals. Part V, the longest section, describes spreading the light by conferences of many different kinds and by means of books and journals: Professor Parkes was instrumental in starting the Journal of Biosocial Science. Part VI, which gives his thoughts on bioethics, on research and the scientist, and on himself, is perhaps the most revealing.

Published by the Galton Foundation, Cambridge, England, 1985. 485 pp, 22 illustrations. Price $£ 20.00$, US\$30.00. ISBN 0907232051.

Order from: Biochemical Society, PO Box 32, Commerce Way, Colchester CO2 8HP, UK. 


\section{Contents}

E. Crognier Child mortality and society in Morocco

page 127

William K. A. AgYei Estimates of fertility and infant and child mortality for Lae urban area of Papua New Guinea: a comparative analysis

page 139

C. G. N. Mascie-Taylor, G. A. Harrison, R. W. Hiorns and J. B. Gibson Husband-wife similarities in different components of the WAIS IQ test

page 149

GlenN D. Wilson and PaUl T. BARRett Parental characteristics and partner choice: some evidence for Oedipal imprinting

page 157

Sergio Zacharias, Eneida Agullera, J. Robert Assenzo and Juan Zanartu Return of fertility in lactating and non-lactating women

page 163

Sandra L. Huffman, Alauddin Chowdhury, Hubert Allen and Luftun Nahar Suckling patterns and post-partum amenorrhoea in Bangladesh

page 171

Dudley L. Poston and Samia M. El-Badry Modernization and childlessness among the governorates of the Arab Republic of Egypt, 1976 page 181

SaAd Gadalla, James MCCaRTHY AND NEERAJ KaK The determinants of fertility in rural Egypt: a study of Menoufia and Beni-Suef governorates

page 195

Michael Humphrey and Heather Humphrey Marital relationships in couples seeking donor insemination

page 209

Ruhul Amin and A. G. Mariam Son preference in Bangladesh: an emerging barrier to fertility regulation

page 221

Charles W. Warren, Richard S. Monteith, J. Timothy Johnson, Roberto Santiso, Federico Guerra and Mark W. Oberle Use of maternal-child health services and contraception in Guatemala and Panama

page 229 Debate

Christine McMurray and David Lucas Fertility and family planning in Papua New Guinea-a comment

page 245

William K. A. Agyei Fertility and family planning in Papua New Guinea-a reply

page 246

Book reviews

V. ReYnolds reviews Primates in Nature (by A. F. Richard)

page 249

Duncan Mitchell reviews The Childless Marriage: An Exploratory Study of Couples Who Do Not Want Children (by E. Campbell)

page 250

Peter Diggory reviews Abortion Practice in Britain and the United States (by C. Francome)

page 251

ISSN 0021-9320 